\title{
Rola biopsii mięśnia szkieletowego w diagnostyce chorób nerwowo-mięśniowych
}

\section{The role of skeletal muscle biopsy in the diagnosis of neuromuscular disorders}

\author{
Aleksandra Nadaj-Pakleza', Biruta Kierdaszuk², Anna Kamińska² \\ IInstitut de Myologie, Hôpital Pitié-Salpêtrière, Paris, France \\ 2Katedra i Klinika Neurologii, Warszawski Uniwersytet Medyczny
}

Neurologia i Neurochirurgia Polska 2010; 44, 5: 481-491

\section{Streszczenie}

Biopsja mięśnia szkieletowego wykonywana w celach diagnostycznych w chorobach nerwowo-mięśniowych umożliwia ocenę rodzaju procesu chorobowego (pierwotnie mięśniowy czy neurogenny), dostarcza informacji o przebiegu (ostry czy przewlekły) oraz stopniu zaawansowania choroby. W wielu przypadkach zastosowanie dodatkowych technik histochemicznych i immunohistochemicznych pozwala na jednoznaczne rozpoznanie takich schorzeń, jak niektóre dystrofie mięśniowe, glikogenozy, miopatie zapalne oraz miopatie wrodzone. Ocena wycinka mięśniowego w mikroskopie elektronowym umożliwia pewne rozpoznanie dystrofii oczno-gardłowej, miopatii mitochondrialnej i wtrętowego zapalenia mięśni.

W niniejszym artykule omówiono objawy kliniczne sugerujące konieczność pobrania wycinka, technikę wykonywania biopsji, zasady wyboru mięśnia do badania, a także praktyczne wskazówki dotyczące przesyłania pobranego wycinka i przygotowania preparatów do oceny w mikroskopie. Przedstawiono ponadto podstawowe zasady dotyczące interpretacji wyniku biopsji mięśnia oraz przydatność kliniczną biopsji mięśnia w dobie zaawansowanej diagnostyki molekularnej.

Słowa kluczowe: biopsja mięśnia, metody diagnostyczne, zmiany patologiczne w mięśniu, miopatia, dystrofia mięśniowa.

\begin{abstract}
Muscle biopsy is required to provide a definitive diagnosis in many neuromuscular disorders. Biopsy findings may indicate whether the pathological process is of neurogenic or myopathic origin. The muscle biopsy may give important information on the course of the disease (acute or chronic) and on the disease stage and progression. The interpretation of muscle biopsy, including histochemical and ultrastructural analysis, is a key factor in the diagnosis of muscular dystrophies, glycogenoses, inflammatory myopathies and congenital myopathies. An assessment of muscle biopsy on electron microscopy enables a definite diagnosis of oculopharyngeal muscular dystrophy, mitochondrial myopathy or inclusion body myositis.

This paper presents an overview of general indications for muscle biopsy, biopsy procedures, as well as transportation and preparation of muscle tissue for final microscopic analysis. The interpretation of specific microscopic findings and a brief discussion on the clinical usefulness of muscle biopsy in the era of molecular diagnosis are also presented.
\end{abstract}

Key words: muscle biopsy, diagnostic methods, pathological changes in muscle, myopathy, muscular dystrophy.

Adres do korespondencii: Biruta Kierdaszuk, Katedra i Klinika Neurologii, Warszawski Uniwersytet Medyczny, ul. Banacha la, 02-097 Warszawa, e-mail:bkierdaszuk@gmail.com

Prace otrzymano: 4.01.2010; przyięto do druku: 13.07.2010 


\section{Wprowadzenie}

Biopsja mięśnia szkieletowego to jedna z ważniejszych metod diagnostycznych w chorobach nerwowo-mięśniowych. Umożliwia ocenę rodzaju procesu chorobowego (pierwotnie mięśniowy czy neurogenny), dostarcza informacji o przebiegu (ostry czy przewlekły) oraz stopniu zaawansowania choroby [1]. Porównanie wyników badań elektrofizjologicznych i histopatologicznych pozwala w większości przypadków na ustalenie rozpoznania, a zastosowanie dodatkowych technik - histochemicznych i immunohistochemicznych - na bliższe scharakteryzowanie wielu schorzeń, takich jak niektóre dystrofie, glikogenozy, miopatie wrodzone czy zapalne. Ocena wycinka mięśniowego w mikroskopie elektronowym umożliwia pewne rozpoznanie dystrofii oczno-gardłowej, miopatii mitochondrialnej czy wtrętowego zapalenia mięśni. Ważnym elementem jest ustalenie wskazań do biopsji i wybór mięśnia, a także poinformowanie laboratorium o wstępnym rozpoznaniu, co umożliwi użycie odpowiednich technik barwienia. Biopsja mięśnia powinna być wykonywana w specjalistycznych ośrodkach mających możliwość zastosowania różnorodnych technik diagnostycznych oraz mających doświadczenie w ocenie tkanki mięśnia szkieletowego.

\section{Wskazania do wykonania biopsji mięśnia}

Do wskazań tych należą:

1. Osłabienie mięśni - biopsja mięśnia jest szczególnie przydatna w diagnostyce przewlekłego osłabienia i zaniku głównie mięśni ksobnych (podejrzenie miopatii lub dystrofii) oraz $\mathrm{w}$ przypadkach opadania mięśni powiek i osłabienia mięśni gałkoruchowych (sugeruje to miopatię mitochondrialną).

2. Nietolerancja wysiłku - nawet niewielki powtarzalny wysiłek w warunkach pracy beztlenowej mięśnia prowadzi do zmęczenia u chorych z glikogenozą, której podejrzenie stanowi wskazanie do wykonania biopsji. Stwierdzenie tego objawu wymaga przede wszystkim wykluczenia miastenii.

3. Ból mięśni - w czasie spoczynku jest charakterystyczny dla miopatii zapalnych. Ból mięśni, który pojawia się w czasie i po wysiłku, oznacza niedobór energii w komórce mięśniowej, co nasuwa podejrzenie miopatii metabolicznej (np. glikogenozy).

4. Mioglobinuria - świadczy o gwałtownym uszkodzeniu włókna mięśniowego, czyli rabdomiolizie. Przebiega zwykle z bólami i osłabieniem mięśni, może być pierwszym objawem wielu chorób, m.in. niedoboru miofosforylazy (choroby McArdle'a), niedoboru fosfofruktokinazy (choroby Taruiego) czy hipertermii złośliwej. Biopsję wykonuje się po ustąpieniu ostrych objawów.

5. Zwiększona aktywność kinazy kreatynowej (creatine kinase - CK) - zależy od nasilenia zmian martwiczych w mięśniu. Największą aktywność CK obserwuje się w chorobach $\mathrm{z}$ ostrym uszkodzeniem włókien mięśniowych, w miopatiach zapalnych i polekowych, w dystrofinopatiach i w miopatiach metabolicznych. Wskazaniem do wykonania biopsji mięśnia jest sytuacja, w której na podstawie wywiadu rodzinnego i objawów choroby nie można ustalić prawdopodobnej przyczyny zwiększenia aktywności CK.

\section{Technika wykonywania biopsji mięśnia}

Mięsień wybrany do biopsji powinien wykazywać kliniczne objawy choroby. Należy jednak unikać mięśni, które uległy znaczemu zanikowi, ponieważ można trafić na fragment przerośnięty tkanką łączną, co uniemożliwi ustalenie rozpoznania. $\mathrm{Z}$ kolei wycinek pobrany z mięśnia niewykazującego osłabienia może nie uwidocznić zmian patologicznych. W przypadku procesu przewlekłego wybiera się mięsień ze średnio zaawansowanym uszkodzeniem, a w przypadku procesu ostrego - mięsień z uszkodzeniem ciężkim lub średnio zaawansowanym. Bada się proksymalny mięsień kończyn górnych lub dolnych, najczęściej mięsień dwugłowy ramienia, mięsień naramienny lub głowę boczną mięśnia czworogłowego uda. W przypadku zajęcia przez proces chorobowy mięśni dystalnych, badaniu można poddać mięsień brzuchaty łydki, piszczelowy przedni lub strzałkowy krótki. Analiza takiej biopsji może być jednak trudna $\mathrm{z}$ powodu braku opracowanych norm składu procentowego włókien i średnicy dla tych grup mięśni i dlatego nie jest polecana w diagnostyce miopatii. Mięsień, z którego pobiera się wycinek, nie powinien być wcześniej poddany badaniu EMG, powinien też być omijany przy wykonywaniu wstrzyknięć domięśsniowych.

Przy pobieraniu biopsji stosuje się znieczulenie miejscowe 1-procentowym roztworem lidokainy. Aby uniknąć artefaktów, nie należy bezpośrednio nastrzykiwać wybranego miejsca środkiem znieczulającym oraz pamiętać o możliwości zmiażdżenia mięśnia poprzez manipulowanie pęsetą. Gwarancję pobrania odpowiedniej tkanki do badania daje wykonanie biopsji przez 
chirurga lub neurologa dobrze znającego anatomię układu mięśniowego. Istnieją dwa sposoby pobierania wycinka mięśniowego - biopsja otwarta i biopsja igłowa. W większości ośrodków stosuje się metodę otwartą. Przemawia za tym zdecydowanie większa czułość tej metody w wykrywaniu drobnych zmian wieloogniskowych oraz fakt, że można ją wykonać u wszystkich pacjentów, bez względu na wiek. Niesie ze sobą niewielkie ryzyko poważnych powikłań, a szycie powięzi szwem rozpuszczalnym nie zawsze bywa konieczne. Zwykle po równoległym do przebiegu włókien nacięciu powięzi brzegi schodzą się samoistnie. Zalecane jest zdjęcie szwów skórnych w 7.-8. dobie. Rana goi się zwykle dobrze i pozostawia jedynie prawie niewidoczną, jednocentymetrową bliznę [1].

Wycinek mięśniowy należy jak najszybciej przetransportować do specjalistycznego laboratorium histopatologicznego. Nie powinno umieszczać się pobranego wycinka w soli fizjologicznej ani w innych płynach. Tuż po pobraniu należy włożyć tkankę do zamkniętego suchego pojemnika i umieścić w termosie z lodem. Nie wolno umieszczać pobranej tkanki w suchym lodzie, ponieważ stwarza to możliwość zamrożenia wycinka i w konsekwencji powstania artefaktów.

W celu oceny morfologicznej wykorzystuje się metody histologiczne, histochemiczne, immunohistochemiczne i ultrastrukturalne [2,3]. Wycinek mięśnia przygotowywany jest do obejrzenia w mikroskopie świetlnym i elektronowym. Pobrany wycinek dzieli się na cztery części - jedną z nich zamraża się w temperaturze $-160^{\circ}$, pozostałe zastają odpowiednio utrwalone lub zamrożone w celu dalszego przechowywania. Do oceny biopsji w mikroskopie świetlnym zamrożone skrawki barwi się przy użyciu następujących metod rutynowych:

1) hematoksylina i eozyna (HE),

2) trichrom Gomoriego,

3) barwienie na aktywność enzymów utleniających:

- dehydrogenaza bursztynianowa (succinate dehydrogenase - SDH),

- dehydrogenaza zredukowanego dinukleotydu pirydynowego (nicotinamide adenine dinucleotide dehydrogenase - NADH),

- dehydrogenaza mleczanowa (lactate dehydrogenase - $\mathrm{LDH}$ ),

4) metoda na aktywność ATPaz - ATPazy miozynowej w pH 9,4 oraz po preinkubacji ATPazy kwaśnej (pH 4,35 i pH 4,3).

Rutynowe badania histochemiczne umożliwiają rozróżnienie włókien oksydacyjnych (typ I) i glikolitycznych (typ II), zmiany o charakterze central core oraz cechy neurogenne (grupowanie włókien jednego typu i zanik grupowy). Za pomocą dodatkowych metod można wykazać obecność tłuszczu we włóknach mięśniowych. W przypadku podejrzenia glikogenoz wykonuje się barwienia kwaśnym odczynnikiem Schiffa (periodic acid-Schiff-PAS), barwienia z użyciem PAS i diastazy, a także barwienia na aktywność fosforylaz. Do dokładnego wyjaśnienia podłoża miopatii metabolicznych konieczne jest wykonanie badań biochemicznych.

W miopatiach zapalnych często obserwuje się nacieki limfocytarne w tkance łącznej okołopęczkowej lub rozproszone w obrębie pęczków. Metody histochemiczne uwidoczniają zmiany w strukturze mitochondriów (włókna „szmatowate”; ragged-red fibers - RRF), niedobory enzymatyczne, obecność wodniczek czy charakterystycznych struktur, takich jak zmiany typu central core i struktury nitkowate.

W celu wykrycia i lokalizacji odpowiednich białek w strukturach włókien mięśniowych stosuje się metody immunohistochemiczne. Obecnie najczęściej wykorzystuje się pośrednią metodę barwienia. Jest to reakcja dwuetapowa polegająca na:

- inkubacji skrawków mięśniowych ze swoistym, nieznakowanym przeciwciałem (tzw. przeciwciałem pierwotnym),

- następnie poddaniu preparatów, w których doszło już do związania pierwotnego przeciwciała $\mathrm{z}$ antygenem tkankowym, działaniu znakowanego (tzn. wtórnego) przeciwciała skierowanego przeciwko immunoglobulinom zwierzęcia, od którego uzyskano przeciwciała pierwotne.

Używa się różnorodnych przeciwciał pierwotnych przeciwko poszczególnym białkom komórki w za leżności od rozpoznania. W ten sposób można wykazać całkowity brak dystrofiny w dystrofii mięśniowej Duchenne'a lub częściowy brak dystrofiny w dystrofii Beckera oraz mozaikowy układ u nosicielek mutacji. Metody immunohistochemiczne pozwalają ponadto na uwidocznienie braku dysferliny, kalpainy 3, sarkoglikanów, emeryny, laminy $\mathrm{A} / \mathrm{C}$, jak również złogów desminy, $\beta$-amyloidu czy innych białek.

W niektórych przypadkach konieczna jest ocena biopsji w mikroskopie elektronowym. Półcienkie skrawki, służące do oceny wstępnej preparatu w mikroskopie świetlnym, barwi się błękitem toluidyny. Skrawki ultracienkie, do oceny w mikroskopie elektronowym, podlegają barwieniu octanem uranylu i dobarwieniu cytrynianem ołowiu. Skrawki utrwala się aldehydem glutarowym i zatapia w żywicach epoksydowych (m.in. Spurr, Araldite, Epon). Metoda ta umożliwia wykrycie 
wielu charakterystycznych zmian ultrastrukturalnych, takich jak obłoniony glikogen w chorobie Pompego, wtręty we wtrętowym zapaleniu mięśni czy dystrofii oczno-gardłowej oraz mitochondria z parakrystalicznymi wtrętami opisywane $\mathrm{w}$ miopatiach mitochondrialnych.

Pozostała tkanka mięśniowa pobrana w czasie biopsji jest przechowywana w temperaturze $-70^{\circ} \mathrm{C}$ i później wykorzystywana m.in. do badań biochemicznych i genetycznych.

\section{Interpretacja wyniku biopsji mięśnia}

Klasyczne metody histologiczne umożliwiają ocenę morfologiczną tkanki mięśniowej. W mikroskopii świetlnej określane są m.in.: kształt i wielkość włókien mięśniowych, lokalizacja jąder, obecność włókien ulegających martwicy lub regeneracji, włókien szkliwiejących, rozszczepionych lub włókien okrężnych, jak również występowanie złogów i wodniczek. Można również stwierdzić przerost tkanki łącznej i nacieki zapalne. Rutynowe metody histologiczne pozwalają określić grupowy zanik włókien w zmianach neurogennych lub typowe cechy uszkodzenia miopatycznego, takie jak martwica włókien, włókna regenerujące lub centralnie położone jądra. Wszystkie te zmiany zalicza się do nieswoistych, czyli mogących wystąpić w wielu różnych chorobach nerwowo-mięśniowych. Zmiany w strukturze włókna mogą być także swoiste, czyli charakterystyczne dla danego schorzenia (tab. 1.) [4]. Należy podkreślić, że pojawienie się pojedynczych zmian swoistych w wycinku nie upoważnia do rozpoznania danej jednostki chorobowej. Niewiele zmian uznaje się za patognomoniczne dla określonego schorzenia. Do tej grupy należą jedynie wtręty wewnątrzjądrowe $\mathrm{w}$ dystrofii oczno-gardłowej i obłoniony glikogen w chorobie Pompego. Zastosowanie metod immunohistochemicznych daje szansę na rozpoznanie miopatii przebiegających z gromadzeniem desminy oraz może wykazać brak dystrofiny lub laminy w grupie postępujących dystrofii mięśniowych. Rozpoznanie może z kolei zostać potwierdzone poprzez ocenę biopsji w mikroskopie elektronowym. Zmiany w ultrastrukturze sarkomerów w miopatiach nemalinowych oraz obecność wtrętów parakrystalicznych $\mathrm{w}$ mitochondriach $\mathrm{w}$ miopatiach

Tabela 1. Najczęściej spotykane patologiczne zmiany swoiste w biopsii mięśnia (zaadaptowano z [4])

Table 1. The most frequent specific pathological changes in the muscle biopsy (adapted from [4])

\begin{tabular}{|c|c|}
\hline Zmiany swoiste & Rozpoznanie \\
\hline central core & miopatia typu central core \\
\hline multiminicores & miopatia typu multiminicore \\
\hline struktury nitkowate & miopatia nemalinowa \\
\hline agregaty tubularne & miopatia z tubularnymi agregatami \\
\hline włókna „szmatowate” & miopatie i encefalomiopatie mitochondrialne \\
\hline gromadzenie glikogenu & glikogenozy \\
\hline obłoniony glikogen & choroba Pompego \\
\hline gromadzenie tłuszczu & miopatie tłuszczowe \\
\hline gromadzenie desminy & miopatie $\mathrm{z}$ gromadzeniem desminy \\
\hline małe włókna z pojedynczymi i ośrodkowo położonymi jądrami & miopatia miotubularna \\
\hline układ aktywności enzymów utleniających w kształcie „szprych” i zanik włókien typu 1 & miopatia centronuklearna \\
\hline „czapeczki” & miopatia typu „czapeczek” \\
\hline ciałka cytoplazmatyczne & miopatia z ciałkami cytoplazmatycznymi \\
\hline ciałka redukujące & miopatia z ciałkami redukującymi \\
\hline $\begin{array}{l}\text { wodniczki zawierające zasadochłonne ziarnistości (rimmed vacuoles), } \\
\text { tubulofilamentarne wtręty w cytoplazmie i/lub w jądrach }\end{array}$ & wtrętowe zapalenie mięśni, miopatia dystalna \\
\hline tubulofilamentarne wtręty typu IBM w cytoplazmie i/lub w jądrach & wtrętowe zapalenie mięśni \\
\hline palisadowate wtręty wewnątrzjądrowe, rimmed vacuoles & dystrofia oczno-gardłowa \\
\hline
\end{tabular}

IBM - rotrętoree zapalenie mięśni (inclusion body myositis) 
mitochondrialnych to tylko niektóre ze zmian charakterystycznych dla określonej choroby nerwowo-mięśniowej, widocznych w mikroskopie elektronowym. W tym miejscu warto wspomnieć, że wiele miopatii i dystrofii ma podobny przebieg i obraz kliniczny. Również badanie EMG i aktywność CK rzadko umożliwiają jednoznaczne rozpoznanie. Często dopiero obecność charakterystycznych zmian w biopsji mięśnia pozwala na sprecyzowanie ostatecznej diagnozy. Dzięki temu możliwe staje się wdrożenie odpowiedniego leczenia (niestety, dotychczas tylko w nielicznych schorzeniach, np. w miopatiach zapalnych i tłuszczowych), ustalenie rokowania oraz poradnictwo genetyczne.

Biopsja mięśnia może okazać się mało przydatna $\mathrm{w}$ diagnostyce niektórych schorzeń nerwowo-mięśniowych, ma również często ograniczone zastosowanie w przypadku dzieci [5]. Do tej grupy należy miastenia, której wstępne rozpoznanie jest oparte na obrazie klinicznym. Potwierdzenie diagnozy przynosi w tym przypadku badanie elektrofizjologiczne (elektrostymulacyjna próba nużliwości i EMG pojedynczego włókna mięśniowego) oraz oznaczenie w surowicy przeciwciał skierowanych przeciw receptorowi dla acetylocholiny. Również w dystrofii miotonicznej obserwuje się zwykle typowy obraz kliniczny, a w EMG - charakterystyczne wyładowania miotoniczne. Także w diagnostyce porażenia okresowego (hiperkalemicznego, hipokalemicznego lub normokaliemicznego) biopsja mięśnia odgrywa drugorzędną rolę, a najczęstszą zmianą występującą w tym schorzeniu jest zwyrodnienie wodniczkowe. Podstawę rozpoznania w tym przypadku stanowi wywiad rodzinny, obraz kliniczny, EMG, seryjne pomiary stężenia potasu i ewentualnie próby prowokacyjne. Wykonanie biopsji mięśnia jest również mało przydatne w diagnostyce miopatii endokrynnych, w których jedynie wykrycie zaburzeń hormonalnych potwierdza rozpoznanie. O rozpoznaniu dystrofii twarzowo-łopatkowo-ramieniowej przesądza z reguły obraz kliniczny. Zapis EMG potwierdza obecność zmian pierwotnie mięśniowych. Podsumowanie wyników z biopsji mięśnia u pacjentów z mialgią pokazało również, że jedynie u $20 \%$ można ustalić rozpoznanie, a wykonanie badania histopatologicznego powinno być poprzedzone wnikliwą analizą objawów klinicznych i badań elektrofizjologicznych [6].

Powyższe przykłady można podsumować stwierdzeniem, że w przypadku obrazu klinicznego jednoznacznie wskazującego na daną chorobę nerwowo-mięśniową $\mathrm{w}$ połączeniu $\mathrm{z}$ wywiadem rodzinnym w pierwszej kolejności w celu ostatecznego ustalenia roz- poznania powinno się wykonać inne badania dodatkowe i badania genetyczne [7].

\section{Biopsja mięśnia w dobie badań molekularnych}

Badanie biopsyjne mięśnia stanowi ważny punkt odniesienia dla innych metod diagnostycznych, jednak często nie jest w stanie rozstrzygnąć, czy proces jest uogólniony czy zlokalizowany oraz jaka jest jego dynamika. Problemy te wynikają z niemożności powtórzenia biopsji w tym samym miejscu oraz pobrania wycinka z kilku mięśni jednocześnie lub z kilku miejsc danego mięśnia. Zdarza się także, że mimo obecności objawów klinicznych obraz biopsji jest prawidłowy. Taki wynik nie rozstrzyga o rozpoznaniu i może być spowodowany niewłaściwym wyborem mięśnia do wycinka.

$\mathrm{O}$ trudnościach diagnostycznych $\mathrm{w}$ chorobach nerwowo-mięśniowych świadczą wyniki badań, w których wstępna diagnoza po wykonaniu biopsji mięśnia została zmieniona w 47\% przypadków [8]. Najczęściej stwierdzano zmiany o charakterze pierwotnie mięśniowym, ale $20 \%$ pacjentów miało zmiany niespecyficzne, a $14 \%$ biopsji opisano jako wycinki prawidłowe. Biopsję mięśnia w cytowanym badaniu określono jako istotną w procesie diagnostycznym w 74\% przypadków [8]. Jej wynik nie tylko umożliwił ustalenie rozpoznania, ale również zmienił dotychczas stosowane leczenie. Tym samym biopsja mięśnia często stanowi swoisty wyznacznik dalszego postępowania lekarza i decyduje o wyborze badań dodatkowych, w tym badań molekularnych.

Symptomatologia chorób mięśni obejmuje w większości przypadków takie objawy, jak osłabienie o nasileniu stałym lub zmiennym, niedowład i zanik mięśni oraz odchylenia w badaniach laboratoryjnych i elektromiograficznych. Badania ostatnich dekad umożliwiają coraz głębsze poznanie poszczególnych jednostek chorobowych i wprowadzają klasyfikację głównie na podstawie zmian molekularnych (tab. 2.-6.) [9-11]. $\mathrm{W}$ procesie diagnostycznym $\mathrm{u}$ wielu pacjentów trudno jest bliżej określić przypuszczalny defekt genetyczny jedynie na podstawie objawów klinicznych i wywiadu rodzinnego, dlatego istotna jest rola badań dodatkowych, w tym szczególnie oceny histopatologicznej i immunohistochemicznej biopsji mięśnia. Przykładem może tu być stwierdzenie w biopsji zmian o charakterze dystrofii (tab. 2.) $[9,11]$. Aktualnie uważa się, że w diagnostyce dystrofii mięśniowych typu Duchenne'a lub Beckera biopsja nadal odgrywa istotną 
Tabela 2. Przykłady korelacij kliniczno-genetycznych w dystrofinopatiach i laminopatiach

Table 2. Examples of phenotype-genotype correlations in dystrophinopathies and laminopathies

\begin{tabular}{|lll|}
\hline \multicolumn{1}{|l}{ Immunohistochemia } & Gen/białko/dziedziczenie* \\
\hline Dystrofinopatie & & \\
\hline dystrofia mięśniowa Duchenne'a & całkowity brak dystrofiny & $D M D /$ dystrofina/XR \\
\hline dystrofia mięśniowa Beckera & częściowy brak dystrofiny & $D M D /$ dystrofina/XR \\
\hline nosicielki mutacji dystrofii mięśniowej Duchenne'a lub Beckera & mozaikowy brak dystrofiny & $D M D /$ dystrofina/XR \\
\hline Laminopatie & & \\
\hline dystrofia Emery'ego-Dreifussa & brak laminy A/C w błonie jądrowej & $L M N A /$ lamina A/C/AD lub AR \\
& brak emeryny w błonie jądrowej & $E M D /$ emeryna/XR \\
& & $F H L 1 /$ białko FHL1/XR \\
& & $S Y N E 1 /$ nespryna 1/AD \\
& & $S Y N E 2 /$ nespryna 2/AD \\
\hline
\end{tabular}

*Dane zaadaptowane $z[9,11]$

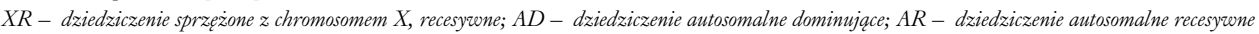

Tabela 3. Przykłady korelacii kliniczno-genełycznych w dystrofiach obręczowo-kończynowych

Table 3. Examples of phenotype-genotype correlations in limb-girdle muscular dystrophies

\begin{tabular}{|c|c|c|}
\hline $\begin{array}{l}\text { Dystrofie obręczowo-kończynowe } \\
\text { (limb-girdle muscular dystrophies - LGMD) }\end{array}$ & $\begin{array}{l}\text { Charakterystyczne } \\
\text { cechy morfologiczne }\end{array}$ & Gen/białko/dziedziczenie* \\
\hline LGMD 1A & cechy dystroficzne & $M Y O T /$ miotylina/AD \\
\hline LGMD 1B & brak laminy $\mathrm{A} / \mathrm{C}$ & $L M N A /$ lamina $\mathrm{A} / \mathrm{C} / \mathrm{AD}$ \\
\hline LGMD 1C & brak kaweoliny-3 & CAV3/kaweolina-3/AD \\
\hline LGMD 1D & cechy dystroficzne & ?/AD \\
\hline LGMD 1E & cechy dystroficzne & ?/AD \\
\hline LGMD $1 \mathrm{~F}$ & cechy dystroficzne & $L G M D$ 1F/?/AD \\
\hline LGMD $1 \mathrm{G}$ & cechy dystroficzne & $L G M D 1 G / ? / \mathrm{AD}$ \\
\hline LGMD 2A & lobulated fibers & CANP3/kalpaina 3/AR \\
\hline LGMD 2B & brak dysferliny & $D Y S F /$ dysferlina/AR \\
\hline LGMD 2C & brak sarkoglikanów & $S G C G / \gamma$-sarkoglikan/AR \\
\hline LGMD 2D & brak sarkoglikanów & $S G C A / \alpha$-sarkoglikan/AR \\
\hline LGMD 2E & brak sarkoglikanów & $S G C B / \beta$-sarkoglikan/AR \\
\hline LGMD 2F & brak sarkoglikanów & $S G C D / \delta$-sarkoglikan/AR \\
\hline LGMD 2G & cechy dystroficzne & $T C A P /$ teletonina/AR \\
\hline LGMD 2H & cechy dystroficzne & TRIM32/TRIM32/AR \\
\hline LGMD 2I & cechy dystroficzne & $F K R P /$ białko związane z fukutiną/AR \\
\hline LGMD 2J & cechy dystroficzne & TTN/titina/AR \\
\hline LGMD 2K & cechy dystroficzne & POMT1/mannozylotransferaza 1 białka $\mathrm{O} / \mathrm{AR}$ \\
\hline LGMD 2L & cechy dystroficzne & ANO5/anoktamina5/AR \\
\hline LGMD 2M & cechy dystroficzne & FKTN/fukutina/AR \\
\hline LGMD 2N & cechy dystroficzne & POMT2/mannozylotransferaza 2 białka $\mathrm{O} / \mathrm{AR}$ \\
\hline LGMD $2 \mathrm{O}$ & cechy dystroficzne & POMGNT1/acetylglukozaminotransferaza/AR \\
\hline
\end{tabular}

*Dane zaadaptowane $z$ [9-11]

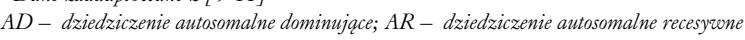

rolę. Wykonanie testów genetycznych u chłopców $z$ podejrzeniem jednej $z$ tych dystrofii umożliwia ustalenie pewnego rozpoznania u $60 \%$ chorych. W przy- padkach, gdy nie stwierdza się delecji ani duplikacji w Xp21, a niemożliwe jest sekwencjonowanie genu dla dystrofiny w poszukiwaniu mutacji punktowych, 
Tabela 4. Przykłady korelacii kliniczno-histopatologicznych w miopatiach zapalnych (zaadaptowano z [15,16])

Table 4. Examples of phenotype-histopathological correlations in inflammatory myopathies (adapted from $[15,16]$ )

\begin{tabular}{|ll|}
\hline Miopatie zapalne & Charakterystyka histopatologiczna \\
\hline zapalenie skórno-mięśniowe & $\begin{array}{l}\text { zanik włókien mięśniowych zlokalizowany głównie na obwodzie pęczków (perifascicular atrophy) } \\
\text { nacieki zapalne wokół naczyń i w omięsnej, złożone w większości z limfocytów B oraz z mniej licznych } \\
\text { limfocytów T CD4+ }\end{array}$ \\
\hline złogi immunoglobulin i dopełniacza w ścianie naczyń mogące prowadzić do ich zamknięcia \\
\hline wtrętowe zapalenie mięśni & $\begin{array}{l}\text { nacieki zapalne złożone z limfocytów T CD8 +, położone wokół niezmienionych włókien mięśniowych } \\
\text { i prowadzące do ich zniszczenia }\end{array}$ \\
\hline & $\begin{array}{l}\text { nacieki zapalne wokół włókien mięśniowych } \\
\text { rimmed vacuoles } \\
\text { tubulofilamentarne wtręty w cytoplazmie i/lub w jądrze }\end{array}$ \\
\hline
\end{tabular}

Tabela 5. Przykłady korelacii kliniczno-genetycznych w miopatiach wrodzonych Table 5. Examples of phenotype-genotype correlations in congenital myopathies

\begin{tabular}{|c|c|}
\hline Miopatie wrodzone & Gen/białko/dziedziczenie* \\
\hline miopatia nemalinowa & $\begin{array}{l}\text { TPM3/tropomiozyna 3/AD } \\
N E B / \text { nebulina/AR } \\
\text { ACTA1/ } \alpha \text {-aktyna/AD } \\
T P M 2 / \text { tropomiozyna 2/AD } \\
T N N T 1 / \text { troponina T typ 1/AR } \\
C F L 2 / \text { kofilina 2/AR }\end{array}$ \\
\hline $\begin{array}{l}\text { miopatia wrodzona } \\
\text { z dysproporcją włókien }\end{array}$ & $\begin{array}{l}\text { ACTA1/ } \alpha \text {-aktyna/AD } \\
S E P N 1 / \text { selenoproteina N1/AR }\end{array}$ \\
\hline $\begin{array}{l}\text { miopatia typu multiminicore } \\
\text { z oftalmoplegią zewnętrzną, } \\
\text { miopatia typu multiminicore, } \\
\text { forma klasyczna }\end{array}$ & $\begin{array}{l}\text { RYR1/receptor rianodynowy } 1 / \mathrm{AR} \\
S E P N 1 / \text { selenoproteina N1/AR }\end{array}$ \\
\hline miopatia centronuklearna & $\begin{array}{l}D N M / \text { dynamina } 2 / \mathrm{AD} \\
\text { BIN1/amfifizyna/AR }\end{array}$ \\
\hline miopatia central core & $R Y R 1 /$ receptor rianodynowy $1 / \mathrm{AR}$ \\
\hline
\end{tabular}

konieczne jest przeprowadzenie biopsji mięśnia w celu wykonania badania immunohistochemicznego z użyciem przeciwciał przeciwko dystrofinie. W niektórych przypadkach konieczne jest również wykonanie immunoblottingu w celu określenia ciężaru molekularnego dystrofiny.

Badanie immunohistochemiczne umożliwia także ustalenie rozpoznania w przypadku dystrofii mięśniowej Emery'ego-Dreifussa. Mutacja może dotyczyć genu na chromosomie X kodującego emerynę. W dziedziczonej autosomalnie dominująco dystrofii Emery'ego-Dreifussa defekt genetyczny dotyczy genu kodującego laminę A/C (tab. 2.) $[9,11]$. W takich sytuacjach badanie immunofluorescencyjne wykazuje brak prawidłowej
Tabela 6. Przykłady korelacii kliniczno-genetycznych w miopatiach miofibrylarnych

Table 6. Examples of phenotype-genotype correlations in myofibrillar myopathies

\begin{tabular}{|c|c|c|}
\hline $\begin{array}{l}\text { Miopatie } \\
\text { miofibrylarne }\end{array}$ & $\begin{array}{l}\text { Immuno- } \\
\text { histochemia }\end{array}$ & $\begin{array}{l}\text { Gen/białko/ } \\
\text { dziedziczenie* }\end{array}$ \\
\hline $\begin{array}{l}\text { miopatia } \\
\text { miofibrylarna } \\
\text { (myofibrillar } \\
\text { myopathy) }\end{array}$ & $\begin{array}{l}\text { nagromadzenie } \\
\alpha \mathrm{B} \text {-krystaliny, } \\
\text { nagromadzenie } \\
\text { desminy } \\
\quad- \\
\quad-\end{array}$ & 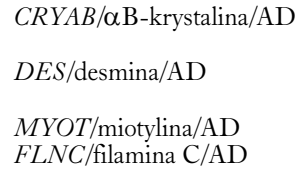 \\
\hline
\end{tabular}

*Dane zaadaptorwane $z[9,11]$

$A D-d z i e d z i c z e n i e$ autosomalne dominujace

emeryny lub laminy w błonach jądrowych włókien mięśniowych.

W grupie dystrofii obręczowo-kończynowych szczegółowe badania immunohistochemiczne ujawniają natomiast zaburzenia w obrębie różnych białek, m.in. w sarkoglikanach, kaweolinie i dysferlinie. Poszczególne postacie tych dystrofii są podobne do siebie pod względem fenotypu, osłabienie dotyczy głównie obręczy barkowej i biodrowej, aktywność CK jest z reguły średnio zwiększona, a badanie elektromiograficzne wykazuje uszkodzenie miogenne. Ukierunkowana na podstawie barwień immunohistochemicznych diagnostyka molekularna pomaga określić typ dziedziczenia i bliżej scharakteryzować prawdopodobny przebieg kliniczny choroby (tab. 3.) [9-11].

Istnieje grupa dystrofii, w których typowy obraz kliniczny przesądza o rozpoznaniu i w których wykonuje się analizę genetyczną $z$ pominięciem biopsji mięśnia. Mowa tu o wspomnianej wcześniej dystrofii miotonicznej oraz o dystrofii twarzowo-łopatkowo-ramieniowej. Stwierdzenie obecności w biopsji mięśnia rimmed vacuoles i palisadowanych wtrętów wewnątrz- 


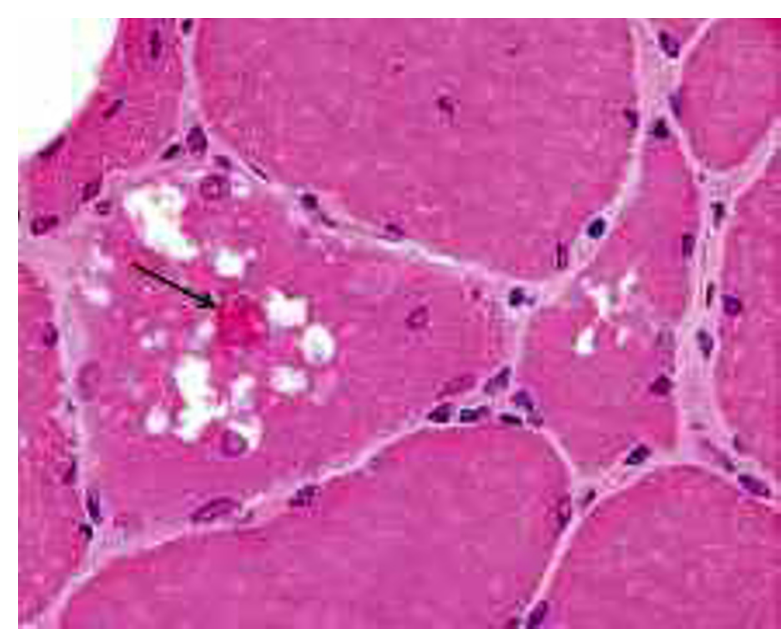

Ryc. 1. Wtrętowe zapalenie mięśni: włókno zawierające wodniczki i kwasochłonny wrręt (strzałka), HE $\times 400$

Fig. 1. Inclusion body myositis (IBM): vacuoles and IBM type inclusion (arrow), HE $\times 400$

jądrowych upoważnia, bez konieczności wykonywania dalszych badań, do rozpoznania dystrofii oczno-gardłowej. Zmiany histopatologiczne nie zawsze są jednak obecne, toteż przy podejrzeniu tej choroby istotne jest wykonanie badań genetycznych [12].

Jedno z częstszych wskazań do wykonania biopsji mięśnia to podejrzenie występowania miopatii zapalnej [13,14]. Biopsja jest szczególnie przydatna w różnicowaniu pomiędzy zapaleniem wielomięśniowym a wtrętowym zapaleniem mięśni. Do cech charakterystycznych w obrazie morfologicznym wtrętowego zapalenia mięśni zalicza się nacieki z komórek jednojądrzastych oraz obecność wodniczek z zasadochłonnymi wtrętami i wtrętów cytoplazmatycznych (tab. 4., ryc. 1.) $[15,16]$. Barwienia immunohistochemiczne wykazują we wtrętach obecność takich białek, jak amyloid- $\beta$, fosforylowane białko tau, $\alpha$-synukleina, apolipoproteina $\mathrm{E}$ i TDP-43 (ryc. 2.) [17-19]. W mikroskopie elektronowym obserwuje się wtręty tubulofilamentarne o charakterystycznej budowie i średnicy, położone zarówno w cytoplazmie, jak i wewnątrzjądrowo (ryc. 3.). W przypadkach rodzinnych IBM stwierdza się mutacje w genie kodującym białko zawierające walozynę (VCP) lub w genie GNE.

Przykładem chorób mięśni, w których zmiany dotyczą ponadto wielu innych układów i narządów, są cytopatie mitochondrialne. Do najczęściej objętych procesem chorobowym należą tkanka mięśniowa i nerwowa. W biopsji mięśnia w większości przypadków obserwuje się włókna „szmatowate” oraz włókna o podwyższonej aktywności w enzymach utleniających i braku aktywności oksydazy cytochromu C [11]. Ze względu na bardzo różnorodny przebieg kliniczny tych chorób i pozostawanie enzymów łańcucha oddechowego pod podwójną kontrolą genomu mitochondrialnego i jądrowego w części przypadków biopsja wykazuje jednak zmiany niespecyficzne. Cennym badaniem uzupełniającym jest niejednokrotnie ocena w mikroskopie elektronowym. Nagromadzenie mitochondriów o nieprawidłowej budowie i układzie grzebieni oraz obecność wewnątrzmitochondrialnych wtrętów parakrystalicznych
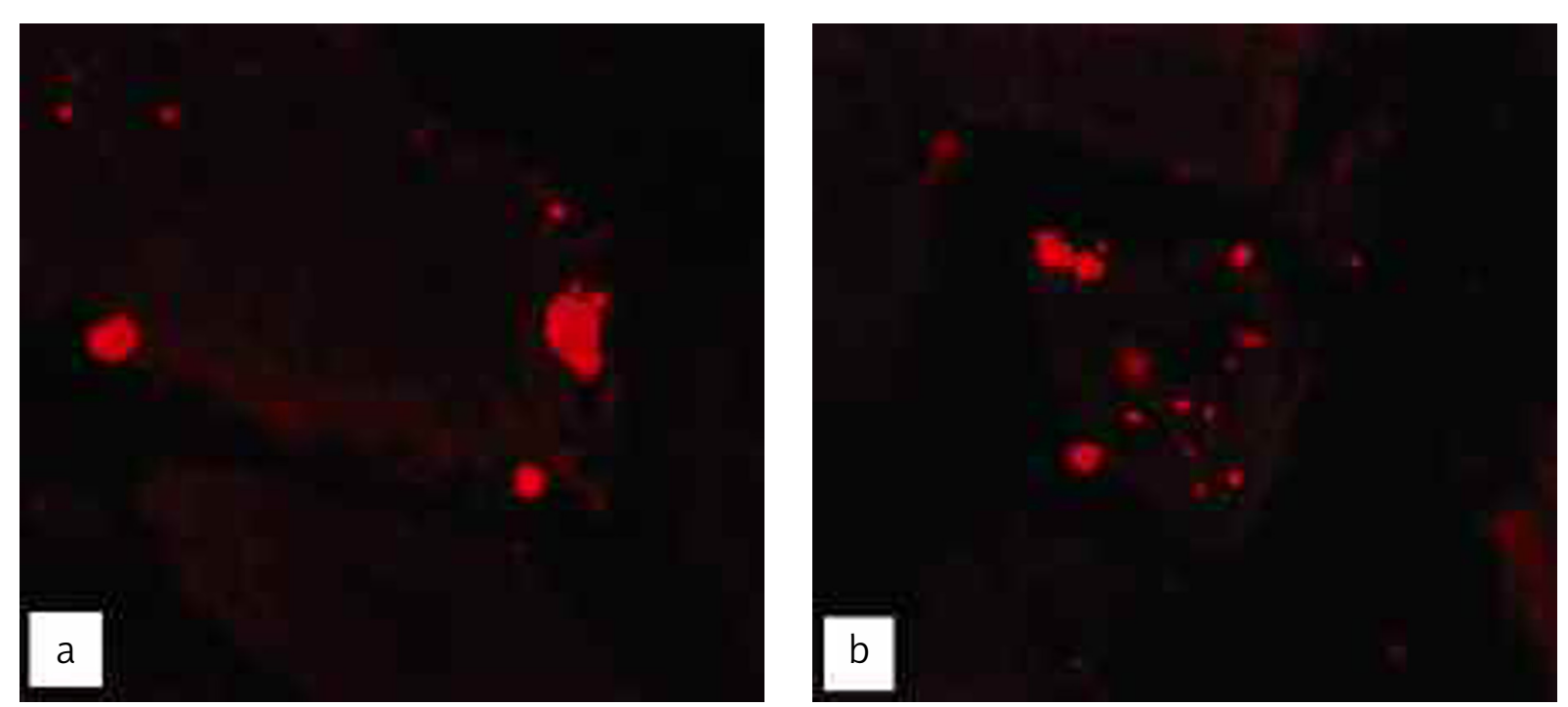

Ryc. 2. Wtrętowe zapalenie mięśni: (a) ztogi $\beta$-amyloidu, ICC $\times 400$; (b) złogi białka tau, ICC $\times 400$

Fig. 2. Inclusion body myositis: (a) $\beta$-amyloid deposits, ICC $\times 400$; (b) tau protein deposits, ICC $\times 400$ 

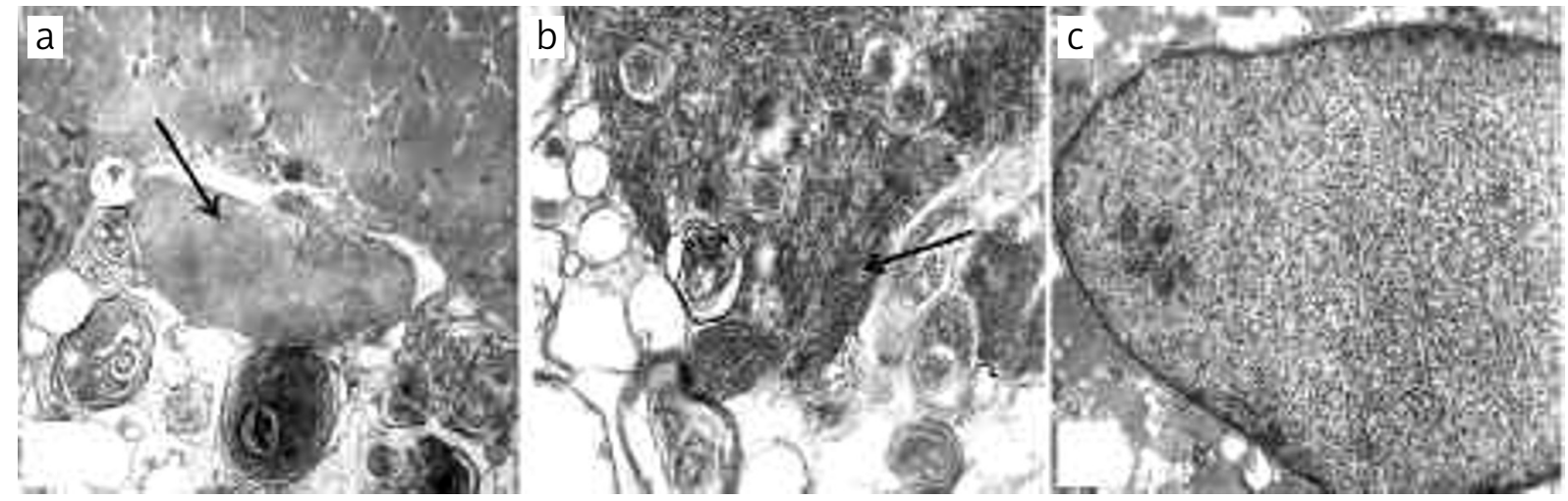

Ryc. 3. Wtrętowe zapalenie mięśni: (a) wtręt w świetle wodniczki (strzałka), EM × 7000; (b) wtręt w świetle wodniczki złożony z tubulofilamentów (strzatka), $E M \times 40$ 000; (c) jadro zawierajace tubulofilamenty, EM $\times 20000$

Fig. 3. Inclusion body myositis (IBM): (a) IBM type inclusion (arrow), EM $\times 7000$; (b) IBM type inclusion containing tubulofilaments (arrow), $E M \times 40000$; (c) nucleus containing tubulofilamentous structures, EM $\times 20000$

może pomóc w ustaleniu rozpoznania. Tkanka mięśniowa może ponadto służyć do badania spektrofotometrycznego aktywności poszczególnych kompleksów łańcucha oddechowego. Diagnostyka molekularna cytopatii mitochondrialnych, oprócz analizy mitochondrialnego DNA uzyskanego z leukocytów krwi obwodowej, wykorzystuje często mięsień pobrany w czasie biopsji. Ze względu na unikalne cechy genetyki mitochondrialnej, takie jak efekt progowy, heteroplazmia, segregacja mito-

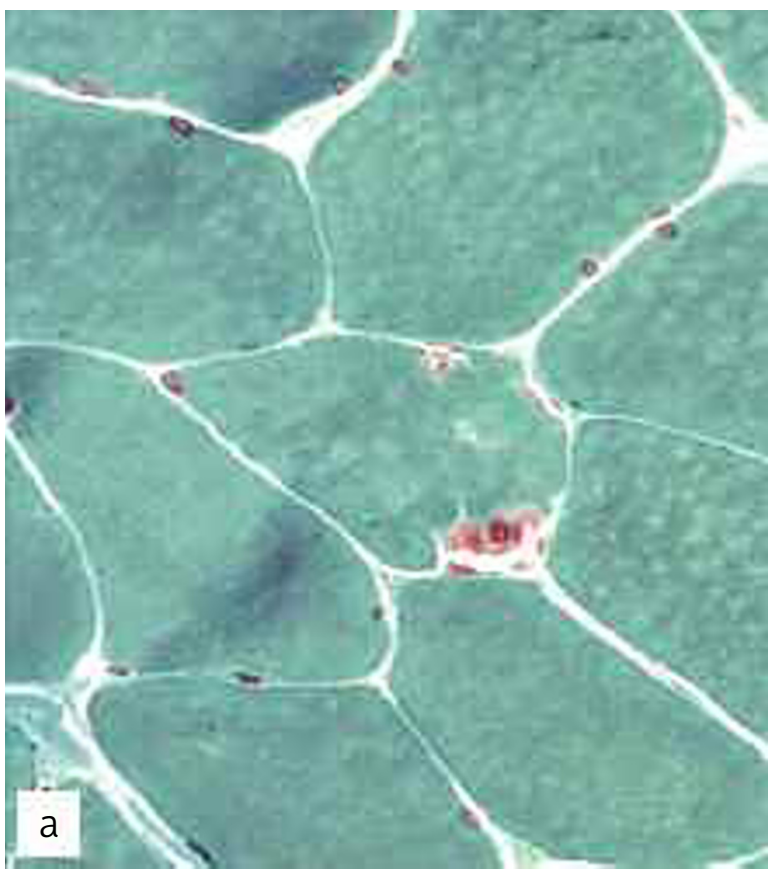

tyczna i dziedziczenie matczyne, wielokrotnie wykrycie mutacji następuje dopiero po badaniu mitochondrialnego DNA uzyskanego z mięśnia szkieletowego.

$\mathrm{Na}$ podstawie specyficznych zmian w morfologii włókien mięśniowych wyodrębniono poszczególne typy miopatii wrodzonych i miopatii miofibrylarnych. Początkowy podział w oparciu o zmiany strukturalne i histochemiczne został uzupełniony o informacje na temat konkretnych defektów genetycznych (tab. 5. i 6.) [9,11].

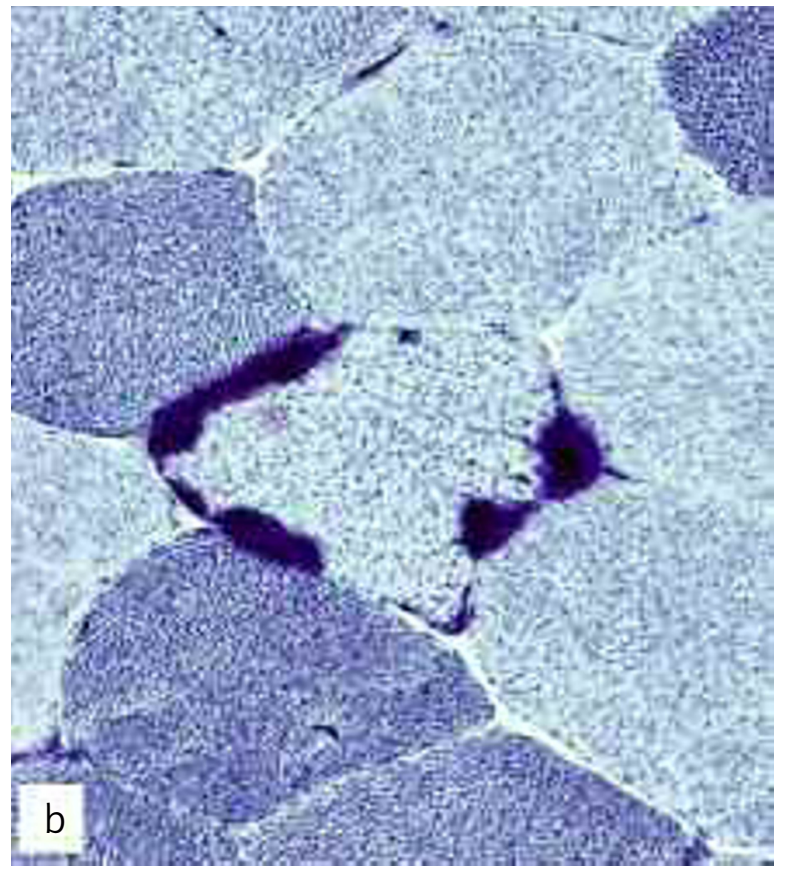

Ryc. 4. Miopatia z tubularnymi agregatami: (a) agregaty tubularne, trichrom Gomoriego $\times 100$; (b) duża aktywność w barwieniu na dehydrogenazę mleczanowq, $\mathrm{LDH} \times 100$

Fig. 4. Myopathy with tubular aggregates: (a) tubular aggregates, Gomori trichrome $\times 100$; (b) tubular aggregates display high activity with lactic dehydrogenase, $\mathrm{LDH} \times 100$ 

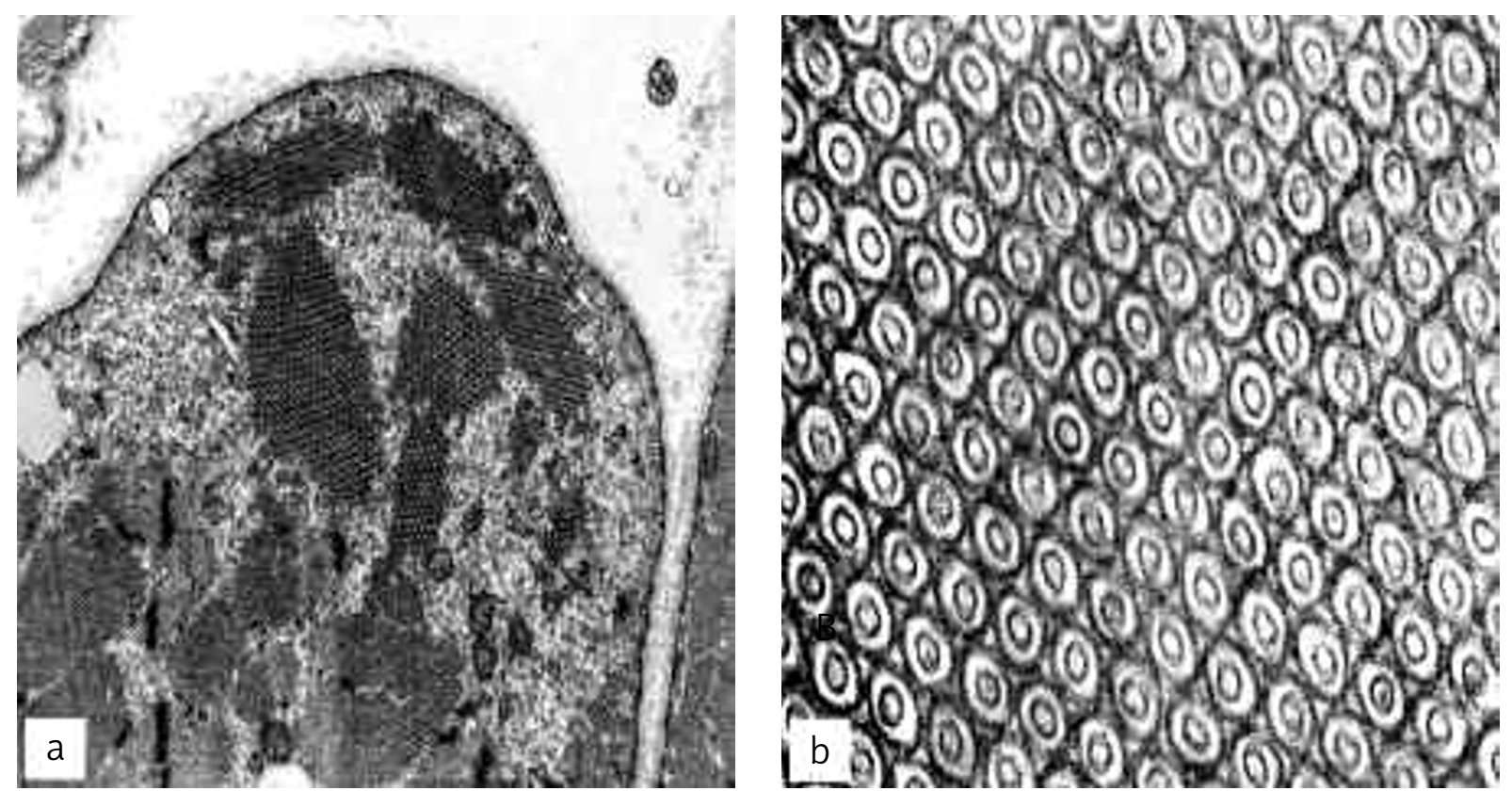

Ryc. 5. Miopatia z tubularnymi agregatami: (a) wtręty złożone z agregatów tubularnych, $E M \times 10000$; (b) agregaty tubularne, $E M \times 100000$

Fig. 5. Myopathy with tubular aggregates: (a) tubular aggregates, $E M \times 10000$; (b) tubular aggregates, $E M \times 100000$

Niecharakterystyczny obraz kliniczny zespołu wiotkiego dziecka lub osłabienia mięśni w połączeniu z obecnością wad kostnych często utrudniał rozpoznanie. Wykonanie badań immunohistochemicznych i molekularnych uznaje się obecnie za kryteria umożliwiające rozróżnienie miopatii nitkowatych, miopatii z tubularnymi agregatami (ryc. 4. i 5.) czy miopatii typu central core.

W dobie ożywionej dyskusji o potrzebie wykonywania biopsji mięśnia warto podkreślić, że wielokrotnie za podobny obraz morfologiczny odpowiadają różne defekty genetyczne. W związku z tym istotne wydaje się wstępne wytyczenie kierunku diagnostyki molekularnej przez biopsję mięśnia. Przykładowo, za obraz miopatii nemalinowej odpowiadają mutacje w różnych genach, dodatkowo o odmiennym sposobie dziedziczenia (tab. 5.) $[9,11]$. Dlatego też obecnie tak ważną rolę odgrywa precyzyjne określanie korelacji pomiędzy obrazem kliniczno-morfologicznym i zmianami molekularnymi.

\section{Podsumowanie}

Informacje, jakie można uzyskać z oceny biopsji mięśnia, zależą przede wszystkim od prawidłowego wyboru mięśnia, zastosowania odpowiednich metod dia- gnostycznych oraz doświadczenia osób wykonujących to badanie. Biopsja mięśnia szkieletowego wykonywana w celach diagnostycznych w chorobach nerwowo-mięśniowych umożliwia ocenę rodzaju procesu chorobowego (pierwotnie mięśniowy czy neurogenny), dostarcza informacji o przebiegu (ostry czy przewlekły) oraz stopniu zaawansowania choroby. W wielu przypadkach zastosowanie dodatkowych technik - histochemicznych i immunohistochemicznych - pozwala na jednoznaczne rozpoznanie wielu schorzeń, takich jak niektóre dystrofie i miopatie wrodzone. W dobie szybkiego rozwoju zaawansowanych metod molekularnych biopsja mięśnia wciąż stanowi ważne badanie diagnostyczne. Analiza wyników badania elektromiograficznego i wyników biopsji mięśnia wykazuje daleko idące korelacje [20]. Uważa się, że do potwierdzenia obserwowanego w badaniach EMG odnerwienia nie jest konieczna biopsja mięśnia, natomiast w przypadku zapisu miogennego diagnostyczna biopsja mięśnia jest często wskazana [21]. Badania histopatologiczne mogą być ponadto szczególnie przydatne $\mathrm{w}$ diagnostyce tzw. trudnych przypadków, gdzie obraz kliniczny oraz wyniki badań elektrofizjologicznych i laboratoryjnych nie są w stanie rozstrzygnąć o ostatecznym rozpoznaniu. 


\section{Oświadczenie}

Autorzy zgłaszają brak konfliktu interesów.

\section{Piśmiennictwo}

1. Brink J. Open muscle biopsy. Oper Tech Gen Surg 2002; 4: 235-238.

2. Hausmanowa-Petrusewicz I. [red.]. Choroby nerwowo-mięśniowe. Wydaronictwo Naukorwe PWN, Warszawa 1999.

3. Dubowitz V., Sewry C.A. The procedure of muscle biopsy. W: Dubowitz V., Sewry C.A. Muscle biopsy: a practical approach. Wyd. 3. Saunders Elsevier, Philadelphia 2007, ss. 3-39.

4. Kamińska A. Histopatologia i histochemia mięśnia szkieletowego w normie i uszkodzeniach pierwotnie mięśniowych. W: Drozdowski W. [red.]. Postępy w diagnostyce i leczeniu chorób mięśni. Medycyna Praktyczna, Kraków 2004, ss. 11-12.

5. Jamshidi R., Harrison M.R., Lee H. i wsp. Indication for pediatric muscle biopsy determines usefulness. J Pediatr Surg 2008; 43: 2199-2201.

6. Filosto M., Tonin P., Vattemi G. i wsp. The role of muscle biopsy in investigating isolated muscle pain. Neurology 2007; 68: 181-186.

7. Anderson J.R. Recommendations for the biopsy procedure and assessment of skeletal muscle biopsies. Virchores Arch 1997; 431: 227-233.

8. Lai C.H., Melli G., Chang Y.J. i wsp. Open muscle biopsy in suspected myopathy: diagnostic yield and clinical utility. Eur J Neurol 2010; 17: 136-142.

9. Gene Table of Neuromuscular Disorders; dostępne na: http://www. musclegenetable.org.

10. Rowland L.P. Merritt's Neurology. $11^{\text {th }}$ ed. Lippincott Williams \& Wilkins, Philadelphia 2005, ss. 893-895.

11. O'Ferrall E.K., Sinnreich M. The role of muscle biopsy in the age of genetic testing. Curr Opin Neurol 2009; 22: 543-553.

12. Nadaj-Pakleza A., Richard P., Lusakowska A. i wsp. Oculopharyngeal muscular dystrophy: phenotypic and genotypic characteristics of 9 Polish patients. Neurol Neurochir Pol 2009; 43: 113-120.

13. Laguno M., Miró O., Perea M. i wsp. Muscle diseases in elders: a 10-year retrospective study. J Gerontol Med Sci 2002; 57: M378-M384.

14. Lacomis D. The utility of muscle biopsy. Curr Neurol Neurosci Rep 2004; 4: 81-86.

15. Dalakas M.C., Hohlfeld R. Polymyositis and dermatomyositis. Lancet 2003; 362: 971-982.

16. Karpati G., Hilton-Jones D., Griggs R.C. Disorders of Voluntary Muscle. $7^{\text {th }}$ ed. Cambridge University Press, Cambridge 2001, ss. 636-659.

17. Dalakas M.C. Sporadic inclusion body myositis - diagnosis, pathogenesis and therapeutic strategies. Nat Clin Pract Neurol 2006; 2: 437-447.

18. Engel W.K., Askanas V. Inclusion-body myositis. Clinical, diagnostic, and pathologic aspects. Neurology 2006; 66 (2 suppl 1): S20-S29.

19. Askanas V., Engel W.K., Nogalska A. Inclusion body myositis: a degenerative muscle disease associated with intra-muscle fiber multi-protein aggregates, proteasome inhibition, endoplasmic reticulum stress and decreased lysosomal degradation. Brain Pathol 2009; 19: 493-506.
20. Buchthal F., Kamieniecka Z. The diagnostic yield of quantified electromyography and quantified muscle biopsy in neuromuscular disorders. Muscle Nerve 1982; 5: 265-280.

21. Al Saleh A., Oware A., Kane N. The correlation between EMG and muscle biopsy. Clin Neurophysiol 2007; 118: e145-e147. 